\title{
Problematika Kompetensi Guru PAI dalam Implementasi Kurikulum 2013 (Studi Kasus di MA Arraudlah Tumapel Gresik)
}

\author{
Ali Ahmad Yenuri \\ Institut Keislaman Abdullah Faqih Gresik \\ aliahmadzainuri@gmail.com
}

\section{Article History: \\ Received : 05-06-2019 \\ Revised : 21-08-2019 \\ Accepted : 05-09-2019}

\begin{abstract}
The 2013 curriculum, apart from emphasizing character education, also adopts scientific lecturers in the learning process. Since the implementation of this curriculum has become a national policy until now, there are still many teachers who have not been able to implement the ideal standard in the education process in Indonesia. Taking the case at MA Ar-Raudlah, Tumapel, and Gresik, this study aims to reveal the problems teachers face in implementing $\mathrm{K}-13$ in their educational institutions. This type of research includes qualitative research with a case study approach. This study concluded that teachers at MA Ar-raudlah Tumapel Gresik had problems implementing the 2013 curriculum, namely those related to pedagogy, professional, and social competency problems. In the pedagogical competence of teachers, it is found that it is still challenging to design and evaluate learning. As for the professional competence issues related to the lack of time in preparing teaching materials, and at the same time, minimal mastery in operationalizing technology. Then the problem of social competence is related to lack of interaction with students and teacher peers in educational institutions.
\end{abstract}

Keyword: Islamic Education, K-13, teacher competence

\section{Pendahuluan}

Pendidikan menurut Ahmad D. Marimba adalah bimbingan atau pimpinan secara sadar oleh si pendidik terhadap perkembangan jasmani dan rohani si terdidik menuju terbentuknya kepribadian yang utama. ${ }^{1}$ Pendidikan adalah usaha sadar dan terencana

${ }^{1}$ Ahmad D. Marimba, Pengantar Filsafat Pendidikan Islam (Bandung: Al-Ma'arif, 1987), 19. 
untuk mewujudkan suasana belajar dan proses pembelajaran agar peserta didik secara aktif mengembangkan potensi dirinya untuk memiliki kekuatan spiritual keagamaan, pengendalian diri, kepribadian, kecerdasan, akhlak mulia serta keterampilan yang diperlukan bagi dirinya, masyarakat dan Negara.

Perkembangan dunia pendidikan dari tahun ke tahun terus mengalami perubahan seiring dengan tantangan dalam menyiapkan sumber daya manusia yang berkualitas dan berdaya saing di era global. Salah satu permasalahan di bidang pendidikan yang dihadapi oleh bangsa Indonesia, yaitu masih rendahnya kualitas pendidikan pada setiap jenjang. Pemerintah terus berupaya untuk meningkatkan mutu pendidikan nasional, salah satunya dengan melakukan penyempurnaan kurikulum. Saat ini dunia pendidikan Indonesia ramai diperbincangkan mengenai penerapan kurikulum 2013. Banyak tanggapan positif dan negatif (pro-kontra) mengenai perubahan kurikulum dari Kurikulum Tingkat Satuan Pendidikan (KTSP) menjadi Kurikulum $2013 .{ }^{2}$

Kurikulum 2013 merupakan kurikulum terbaru yang mulai dilaksanakan pada tahun pelajaran 2013/2014 pada sekolah yang ditunjuk pemerintah, maupun sekolah yang sudah siap melaksanakannya. Di dalam kurikulum 2013 lebih ditekankan pada pendidikan karakter, pendidikan karakter dalam kurikulum 2013 bertujuan untuk meningkatkan mutu proses dan hasil pendidikan, yang mengarah pada pembentukan budi pekerti dan akhlak mulia peserta didik secara utuh, terpadu dan seimbang, sesuai dengan standar kelulusan pada setiap satuan pendidikan.

Hampir semua usaha reformasi dalam pendidikan seperti pembaruan kurikulum dan penerapan metode pembelajaran telah dilakukan. Tetapi tanpa guru yang mampu menguasai bahan ajar dan strategi pembelajaran, maka segala upaya peningkatan mutu pendidikan tidak akan mencapai hasil yang optimal. Dan jika guru memiliki kesiapan yang memadai, siap dalam segi kualifikasi dan kompetensi serta siap dalam hal kesamaan pemahaman paradigma pendidikan yang dijabarkan didalam kurikulum, maka pelaksanaan kurikulum dapat berhasil.

Dalam Undang-undang nomor 14 tahun 2005 tentang guru dan dosen bab 1 ketentuan umum pasal 1 diperoleh definisi guru sebagai berikut : “Guru adalah pendidik profesional dengan tugas utama mendidik, mengajar,membimbing, mengarahkan, melatih, menilai, dan mengevaluasi peserta didik pada pendidikan anak usia dini jalur pendidikan formal, pendidikan dasar, dan pendidikan menengah". ${ }^{3}$

Dengan mengikuti prosedur pengembangan kurikulum berdasarkan kompetensi, diharapkan pengembangan kurikulum itu benar-benar didasarkan atas tuntutan kompetensi, bukan hanya didasarkan atas bahan-bahan yang bersifat apriori saja.

\footnotetext{
2 Elwien Sulistya Ningrum \& Ahmad Yusuf Sobri, "Implementasi Kurikulum 2013 di sekolah dasar", Jurnal Manajemen Pendidikan, volume 24, no 5 (Maret, 2015), 416-423.

${ }^{3}$ Undang-undang Republik Indonesia No.14 tahun 2005, tentang Guru dan Dosen (Bandung: Citra Umbara, 2006), 2. 
Karena itu perlulah guru memiliki kompetensi untuk menunjukkan profesionalitas guru dalam menjalankan kurikulum. ${ }^{4}$

Sekolah Madrasah Aliyah (MA) Arraudlah merupakan sekolah yang sudah menerapkan kurikulum 2013 pada awal tahun pelajaran 2014/2015. Dalam rangka melaksanakan kurikulum 2013, sekolah ini sudah melakukan beberapa persiapan yang mana bisa dilihat dari sumber belajar yang mendukung dan usaha yang sudah ditempuh oleh guru-guru. ${ }^{5}$

Akan tetapi tidak bisat dipungkiri bahwa masih terjadi hambatan-hambatan dalam menerapkan kurikulum 2013. Salah satu hambatan tersebut adalah belum semua guru PAI memahami kurikulum 2013 secara utuh dan belum sepenuhnya bisa mengelola pembelajaran dengan baik. Walaupun respon terhadap kurikulum 2013 sudah baik. ${ }^{6}$ Keberhasilan kurikulum sebagian besar terletak ditangan guru, kurangnya kemampuan guru dalam mengelola pembelajaran akan menjadikan proses pembelajaran tidak berjalan aktif dan produktif.

Berdasarkan uraian di atas dapat diketahui bahwa banyak problem-problem guru PAI dalam mengimplementasikan kurikulum 2013 di MA Ar-Raudlah Tumapel Gresik. Maka penulis mencoba mendefinisikan tentang bagaimana problematika kompetensi pedagogik, kepribadian dan sosial guru PAI di MA Arraudlah Tumapel Gresik.

Penelitian ini menggunakan metode kualitatif dengan pendekatan studi kasus. Dengan mewawancarai guru pada mata pelajaran PAI (Fikih, Akidah akhlak, Sejarah Kebudayaan Islam dan Alqur'an hadits), sebagai pelaku utama yang menerapkan kurikulum 2013 dalam proses pembelajaran. Analisis data dilakukan dengan proses mencari dan menyusun secara sistematis data yang diperoleh dari hasil wawancara, catatan lapangan, dan dokumentasi, dengan cara mengelompokkan data sampai membuat kesimpulan. ${ }^{7}$

\section{Pendidikan Agama Islam Sebagai Mata Pelajaran}

Hubjb Menurut Marimba yang dikutip Ahmad Tafsir pendidikan adalah bimbingan atau pimpinan secara sadar oleh pendidik terhadap pertumbuhan jasmani dan rohani anak didik menuju terbentuknya kepribadian yang utama. Pendidikan yang dilakukan oleh lembaga-lembaga penyelenggara harus mampu melakukan pengembangan segala bidang, baik intelektual lintas maupun spiritual (kecerdasan agama). ${ }^{8}$

Berdasarkan penjelasan diatas, maka pendidikan Islam dapat diartikan sebagai proses transinternalisasi pengetahuan dan nilai-nilai Islam kepada peserta didik melalui

${ }^{4}$ Lias Hasibuan, Kurikulum dan Pemikiran Pendidikan ( Jakarta: Gaung persada (GP Press), 2010), 124.

${ }^{5}$ Moch Nur Kholis, wawancara, Gresik, 19 November 2019.

${ }^{6}$ Ahmad Sofyan wawancara, Tumapel, 19 November 2019.

${ }^{7}$ Sugiono, Metode Penelitian Kuantitatif, Kualitatif, dan R\&D (Bandung. Alfabeta, t.t), 244.

${ }^{8}$ Mahfud, Pembelajaran Pendidikan Agama Islam Berbasis Multietnik (Yogyakarta: CV Budi Utama, 2015), 8. 
pengajaran, pembiasaan, bimbingan, pengasuhan, pengawasan, dan pengembangan potensinya, guna mencapai keselarasan dan kesempurnaan hidup didunia dan akhirat. ${ }^{9}$

Prinsip menjadikan Al-Qur'an dan Sunnah sebagai dasar pendidikan Islam bukan hanya dipandang sebagai kebenaran keyakinan semata. Lebih jauh kebenaran itu juga sejalan dengan kebenaran yang dapat diterima oleh akal yang sehat dan bukti sejarah. ${ }^{10}$

Tujuan dari Pendidikan Agama Islam adalah untuk meningkatkan pengetahuan dan pemahaman tentang ajaran Islam, meningkatkan keterampilan dalam prakteknya, dan meningkatkan pengamalan ajaran Islam dalam kehidupan sehari-harinya.

\section{Kompetensi Guru dalam Proses Pembelajaran}

Menurut Kamus Umum Bahasa Indonesia, kompetensi berarti (kewenangan) kekuasaan untuk menentukan atau memutuskan suatu hal. Pengertian dasar kompetensi (competency) yakni kemampuan atau kecakapan. ${ }^{11}$ Sementara itu kompetensi guru adalah kemampuan seorang guru dalam melaksanakan kewajibankewajiban secara bertanggung jawab dan layak.

Undang-undang Republik Indonesia Nomor 14 Tahun 2005 Tentang Guru dan Dosen menyatakan bahwa kompetensi adalah seperangkat pengetahuan, keterampilan, dan perilaku yang harus dimiliki, dihayati dan dikuasai oleh guru atau dosen dalam melaksanakan tugas keprofesionalan.

Seperti dikemukakan dalam peraturan Menteri Pendidikan Nasional Republik Indonesia Nomor 16 Tahun 2007 tentang Standar Kualifikasi Akademik dan Kompetensi Guru, bahwa kompetensi yang harus dimiliki oleh tenaga guru antara lain: kompetensi pedagogik, kompetensi kepribadian, kompetensi profesional dan kompetensi sosial yang diperoleh melalui pendidikan profesi. Keempat kompetensi tersebut terintegrasi dalam kinerja guru. ${ }^{12}$

1. Kompetensi Pedagogik

Kompetensi pedagogik adalah kemampuan mengelola pembelajaran peserta didik yang dapat dilihat dari indikator meliputi: pemahaman terhadap peserta didik, perancangan dan pelaksanaan pembelajaran, evaluasi hasil belajar, dan pengembangan peserta didik untuk mengaktualisasikan berbagai potensi yang dimilikinya. ${ }^{13}$

2. Kompetensi Kepribadian

Dalam Standar Nasional Pendidikan, penjelasan pasal 28 ayat 3 butir b, dikemukakan bahwa kompetensi kepribadian adalah kemampuan yang mantap, stabil, dewasa, arif, dan berwibawa menjadi teladan bagi peserta didik dan berakhlak mulia. ${ }^{14}$

${ }^{9}$ Ramayulis, Ilmu Pendidikan Islam ( Jakarta: Kalam Mulia, 2002), 38.

10 Ramayulis, Ilmu Pendidikan, 194.

11 Moh Uzer Usman, Menjadi Guru Profesional ( Bandung: Remaja Rosdakarya, 2005), 14. 2014),29.

12 E Mulyasa, Guru dalam Implementasi Kurikulum 2013 (Bandung: PT Remaja Rosdakarya,

${ }^{13}$ E Mulyasa, Standar Kompetensi dan Sertifikasi Guru (Bandung: Remaja Rosdakarya, 2011),173.

14 Ibid., 117. 
3. Kompetensi Profesional

Dalam Standar Nasional Pendidikan, penjelasan pasal 28 ayat 3 butir c dikemukakan bahwa kompetensi profesional adalah kemampuan penguasaan materi pembelajaran secara luas dan mendalam yang memungkinkan membimbing peserta didik memenuhi standar kompetensi yang diterapkan dalam standar nasional pendidikan. ${ }^{15}$

4. Kompetensi Sosial

Dalam standar Nasional Pendidikan, penjelasan pasal 28 ayat 3 yang dimaksud dengan kompetensi sosial adalah kemampuan guru sebagai bagian dari masyarakat untuk berkomunikasi dan bergaul secara efektif dengan peserta didik, sesama pendidik, tenaga kependidikan, orang tua/wali peserta didik, dan masyarakat sekitar. ${ }^{16}$

\section{Kurikulum 2013}

Kata "kurikulum" berasal dari bahasa Yunani yang semula digunakan dalam bidang olahraga, yaitu currere yang berarti jarak tempuh lari, yakni jarak yang harus ditempuh dalam kegiatan berlari mulai dari start hingga finish. Definisi kurikulum yang tertuang dalam UU Sisdiknas Nomor 20/2003 adalah seperangkat rencana dan pengaturan mengenai tujuan, isi dan bahan pelajaran serta cara yang digunakan sebagai pedoman penyelenggaraan kegiatan pembelajaran untuk mencapai tujuan pendidikan tertentu. ${ }^{17}$

Kurikulum 2013 mengusung tema: menghasilkan insan Indonesia yang produktif, kreatif, inovatif, afektif melalui penguatan sikap, keterampilan dan pengetahuan yang terintegrasi. Untuk merealisasikan hal tersebut, dalam implementasi kurikulum, guru perlu merancang pembelajaran efektif dan bermakna (menyenangkan), memilih pendekatan pembelajaran yang tepat, mengembangkan kreativitas secara tuntas dan mengembangkan pembelajaran.

Salah satu yang menentukan keberhasilan implementasi kurikulum 2013 adalah kreativitas guru, karena guru merupakan faktor penting yang besar pengaruhnya, bahkan sangat menentukan berhasil-tidaknya peserta didik dalam belajar. Tugas guru tidak hanya menyampaikan informasi kepada peserta didik, tetapi harus kreatif memberikan layanan dan kemudahan belajar (facilitate learning) kepada seluruh peserta didik, agar mereka dapat belajar dalam suasana yang menyenangkan, gembira, penuh semangat, tidak cemas, dan berani mengemukakan pendapat secara terbuka. ${ }^{18}$

Rancangan dalam menciptakan iklim pembelajaran yang kondusif, dan pembelajaran yang dapat membangkitkan rasa ingin tahu peserta didik, pembelajaran

15 Ibid., 135.

${ }^{16}$ Ibid., 173.

${ }^{17}$ Muhaimin, Pengembangan Kurikulum Pendidikan Agama Islam di Sekolah (Jakarta:Rajawali Pers, 2014), 1-2.

18 E Mulyasa, Pengembangan dan Implementasi Kurikulum 2013 (Bandung: PT Remaja Rosdakarya Offset, 2013), 41-42.

P-ISSN(2549-7987); E-ISSN (2550-0341)

Ali Ahmad Yenuri | 306 
harus diorientasikan kepada kepentingan peserta didik, sesuai dengan karakteristiknya. Oleh karena itu, guru harus mengubah metode pembelajaran yang biasanya dilakukan, yakni pembelajaran yang berpusat pada guru (TCL) ke metode yang berpusat pada peserta didik (SCL). ${ }^{19}$

\section{Problematika Kompetensi Guru PAI dalam Implementasi Kurikulum 2013 di MA Arraudlah Tumapel Gresik}

\section{Problem Kompetensi Pedagogi}

Menurut E Mulyasa untuk menyukseskan implementasi kurikulum 2013 guru yang bermutu adalah kuncinya, yang mana senantiasa meningkatkan kualitas dirinya untuk memperoleh kompetensi melalui berbagai kegiatan, baik secara kelompok maupun secara mandiri, karena pada saat ini diperlukan guru yang mandiri terutama dalam kaitannya dengan masalah mutu. ${ }^{20}$ Namun pada kenyataannya guru PAI di MA Arraudlah masih mengalami problem terkait kompetensi yang dimilikinya.

problematika kompetensi pedagogik sebagian guru PAI di MA Arraudlah Tumapel Gresik yang pertama adalah ketidakmampuannya guru dalam memahami karakteristik peserta didik dalam aspek intelektualnya, yang mana minim sekali minat baca peserta didik dalam pembelajaran, kemudian dalam aspek moral, peserta didik sering ramai dan acuh sendiri saat pembelajaran berlangsung sehingga membuat kurang lancarnya sebuah proses pembelajaran. yang kedua adalah permasalahan dalam merancang sebuah perencanaan pembelajaran dan masih kurangnya pemahaman terkait metode sebuah pembelajaran oleh guru, juga masih terbatasnya media yang menunjang sebuah pembelajaran sehingga membuat guru untuk menerapkan strategi maupun metode yang selalu sama dalam setiap pembelajaran.

Evaluasi merupakan salah satu rangkaian kegiatan dalam meningkatkan kualitas, kinerja, atau produktivitas suatu lembaga dalam melaksanakan programnya. Melalui evaluasi akan diperoleh tentang apa yang telah dicapai dan mana yang belum, dan selanjutnya informasi ini digunakan untuk perbaikan suatu program. ${ }^{21}$ guru PAI MA Arraudlah belum bisa meningkatkan kualitas evaluasinya dikarenakan kurang bisanya mengatur waktu yang mana membuat guru tersebut tidak bisa menyelesaikan KD tersebut dalam satu pertemuan. Dan juga tidak bisa melakukan penilaian setiap pertemuan. Begitu juga kemampuan peserta didiknya yang belum memuaskan sehingga membuat guru kerepotan dan terus menerus melakukan evaluasi.

Problematika yang keempat yakni guru PAI masih mengalami kesulitan dalam mengembangkan potensi peserta didik, karena peserta didik sendiri kurang adanya

\footnotetext{
${ }^{19}$ E Mulyasa, Guru Dalam Implementasi, 65.

${ }^{20}$ E Mulyasa, Guru dalam Implementasi Kurikulum 2013 (Bandung: PT Remaja Rosdakarya, 2014), 14.

${ }^{21}$ Djemari Mardapi, pengukuran, penilaian, dan evaluasi pendidikan, (Yogyakarta: Nuha Medik, 2012), 4. 
minat maupun motivasi untuk mengembangkan kemampuan belajarnya baik dalam bidang akademik maupun non akademiknya.

\section{Problematika Kompetensi Kepribadian}

Kompetensi kepribadian guru PAI di MA Arraudlah dikatakan sudah baik, dikarenakan masih ada kemauan untuk terus memperbaiki, setelah melalui penelitian dan hasil wawancara dengan guru PAI MA Arraudlah ini ternyata sudah menampilkan pribadi yang stabil dalam menjalankan pendiriannya, yang mana tetap konsisten dan tidak lengah saat mendapati siswa yang tidak mengikuti pelajaran.

Selain itu juga beliau sudah berusaha memberikan contoh maupun teladan kepada peserta didik seperti yang peneliti lihat sendiri saat guru berjumpa dengan siswa, siswa menyapa dengan memberi salam dan guru membalas salam dengan senyuman, karena dengan hal kecil seperti itu sudah memberi nilai positif sendiri kepada peserta didik.

Tetapi masih ada problem kepribadian guru yang mana masih ada guru PAI di MA Arraudlah yang kurang disiplin dalam hal mengatur waktu dikarenakan berbenturan dengan pelajaran lain ditempat lain dan terkadang ada kendala yang lainnya yang mengharuskan beliau datang terlambat. Sehingga memotong waktu pembelajaran.

Kedisiplinan ini diperlukan oleh siapapun dan dimanapun seseorang berada, hal itu disebabkan dimanapun seorang berada, disana selalu ada peraturan atau tata tertib. Apabila guru mengabaikan disiplin maka peserta didik akan belajar banyak tentang keburukannya, dan guru yang tidak disiplin akan susah mendisiplinkan siswanya.

\section{Problematika Kompetensi Profesional}

Dalam Standar Nasional Pendidikan, penjelasan pasal 28 ayat 3 butir c dikemukakan bahwa kompetensi profesional adalah kemampuan penguasaan materi pembelajaran secara luas dan mendalam yang memungkinkan membimbing peserta didik memenuhi standar kompetensi yang diterapkan dalam standar nasional pendidikan. ${ }^{22}$

Terkait kemampuan kompetensi profesional dalam implementasi kurikulum 2013 masih diperoleh problem dari guru PAI MA Arraudlah, problem yang pertama dalam penyusunan bahan ajar, dikarenakan terbatasnya sarana prasarana yang dimiliki sekolahan membuat guru kesulitan dalam memilih bahan ajar, dan kurang adanya kekreatifan guru dalam memanfaatkan bahan ajar sehingga membuat guru sendiri juga kesulitan.

Problem yang kedua dalam penyusunan program pembelajaran, masih ada yang bingung terkait waktu pembelajaran yang tidak dapat dipastikan dikarenakan khawatir ada acara di lembaga maupun ditempat yang lain yang tidak bisa diduga dan hal itu akan mengganggu pembelajaran dengan kata lain masih belum bisa menentukan hari yang

\footnotetext{
${ }^{22}$ E Mulyasa, Standar Kompetensi, 135. 
efektif dan tidak. Selanjutnya dalam penguasaan teknologi komputer yang masih minim sekali dikuasi oleh guru PAI MA Arraudlah, membuat guru tersebut kerepotan dalam menyusun program pembelajaran.

Problematika yang ketiga adalah berhubungan dengan penilaian, dikarenakan hasil peserta didik banyak yang tidak mencapai KKM dan terpaut jauh sekali, membuat guru PAI selalu melakukan remidi sampai hasilnya memenuhi target. Selain itu kesulitan dalam penilaian aspek sikap yang mana ada siswa yang kurang tepat pada saat memberikan jawaban pada penilaian diri. Tetapi guru PAI MA Arraudlah mengambil langkah dalam penilaian sikap dengan selalu berusaha secara kontinu untuk meilhat konsistensi siswa dalam bersikap baik disekolah maupun dirumah, agar guru PAI MA Arraudlah bisa melakukan pengamatan dan bisa mendeskripsikan sendiri perilaku mereka.

\section{Problematika Kompetensi Sosial}

Guru disamping mampu melaksanakan tugasnya masing-masing di sekolah, mereka juga diharapkan dapat dan mampu melakukan tugas-tugas hubungan dengan masyarakat. Mereka mengetahui aktifitas masyarakat, paham adat-istiadat masyarakat dan bisa membawa diri ditengah-tengah masyarakat, untuk mencapai hal itu diperlukan kompetensi dan perilaku guru yang cocok dengan struktur sosial masyarakat setempat. Kompetensi sosial guru PAI MA Arraudlah sudah dalam kategori baik, dilihat dari hubungan baik guru-guru dengan lingkungan sekolah sekitar, kemampuan komunikasi guru dengan lingkungan sekolah dan masyarakat juga sudah baik.

Dalam "Kode Etik Guru" pasal 7 disebutkan bahwa guru memelihara hubungan seprofesi, semangat kekeluargaan dan kesetiakawanan sosial. Ini berarti bahwa: pertama, guru hendaknya menciptakan dan memelihara hubungan sesama guru dalam lingkungan kerja. Kedua, guru hendaknya menciptakan dan memelihara semangat kekeluargaan dan kesetiakawanan didalam dan diluar lingkungannya. ${ }^{23}$ Dan guru PAI MA Arraudlah sudah memenuhi kode etik guru tersebut.

Sehubungan dengan pemberlakuan kurikulum 2013 oleh menteri pendidikan dan kebudayaan, mata pelajaran TIK tidak lagi diajarkan disekolah, sebagai konsekuensinya seluruh guru harus memiliki pengetahuan TIK dan kemudian menerapkannya secara terintegrasi di dalam pembelajaran.

Tetapi di MA Arraudlah masih terdapat problem pada kompetensi sosial guru PAI dalam menggunakan teknologi informasi dan komunikasi secara fungsional, dikarenakan keterbatasan sarana prasarana dan media di sekolah, juga kendala waktu dalam menyiapkan bahan ajar, selain itu juga kurangnya pengetahuan guru PAI terkait TIK (teknologi informasi dan komunikasi).

\section{Solusi Alternatif dalam Mengatasi Problem Kompetensi Guru PAI}

${ }^{23}$ Janawi, Kompetensi Guru (Bandung: Alfabeta, 2012), 135. 
Terlepas dari semua itu, guru PAI MA Arraudlah juga mengusahakan untuk meningkatkan kompetensi yang dimilikinya. Diantaranya dengan mengikuti workshop dan pelatihan-pelatihan pengembangan pembelajaran kurikulum 2013, selain itu juga konsultasi maupun sharing dengan guru yang lain dan teman MGMP, selanjutnya mengevaluasi diri dan menyempatkan membaca buku untuk mendapatkan informasi yang lebih banyak lagi terkait proses pembelajaran agar bisa meningkatkan ke kreatifan dalam mengolah sebuah pembelajaran.

\section{Kesimpulan}

Berdasarkan hasil pembahasan, berkaitan dengan Problematika Kompetensi Guru PAI dalam Implementasi Kurikulum 2013 di MA Arraudlah Tumapel Gresik, dapa ditarik kesimpulan sebagai berikut:

Pertama, kompetensi pedagogik kendala yang pertama terkait permasalahan terhadap ketidakmampuan guru dalam memahami karakteristik peserta didik dari aspek intelektual dan moralnya, yang kedua merancang sebuah perencanaan pembelajaran dikarenakan keterbatasan media, kurangnya penguasaan guru terkait metode pembelajaran dan peserta didik yang kurang antusiasnya dalam belajar, ketiga kesulitan dalam evaluasi hasil belajar siswa dikarenakan terlalu banyaknya indikator dalam penilaian sehingga mengharuskan guru untuk sering melakukan evaluasi yang bisa membuat peserta didik merasa bosan dan terbebani dan kemampuan hasil peserta didik yang kurang memuaskan, dan yang terakhir kesulitan dalam mengembangkan potensi peserta didik karena kurang adanya minat dan motivasi dalam diri peserta didik.

Kedua, Kompetensi kepribadian: kendala dalam hal kedisiplinan guru yang sering terlambat dalam memasuki pelajaran. Karena terbenturnya waktu mengajar ditempat lain dan adanya kepentingan mendadak yang membuat guru memotong waktu pelajaran.

Ketiga, Kompetensi profesional: kesulitan dalam menyusun bahan ajar, karena terbatasnya sarana prasarana maupun media dan banyaknya kesibukan yang membuat guru tidak sempat membuat bahan ajar, yang kedua kendala dalam menyusun program pembelajaran, karena kurang tau pastinya waktu yang efektif untuk pembelajaran karena terkadang ada acara dari lembaga maupun lainnya yang tidak diduga-duga, dan karena kurangnya penguasaan terkait teknologi Komputer sehingga meminta bantuan dalam menyusunnya, kendala yang ketiga dalam penilaian terutama pada aspek sikap yang mana guru dituntut untuk mengetahui sikap satu persatu peserta didik, dan karena hasil pembelajaran peserta didik yang tidak mencapai target sehingga membuat guru selalu memberikan remidi dan tugas diluar kelas. 


\section{DAFTAR PUSTAKA}

D Marimba, Ahmad. Pengantar Filsafat Pendidikan Islam. Bandung : Al-Ma'arif , 1987.

Hasibuan, Lias. Kurikulum dan Pemikiran Pendidikan. Jakarta: Gaung persada (GP Press), 2010.

Janawi, Kompetensi Guru. Bandung: Alfabeta, 2012.

Mahfud, Pembelajaran Pendidikan Agama Islam Berbasis Multietnik. Yogyakarta: CV Budi Utama, 2015.

Mahfud, Pembelajaran Pendidikan Agama Islam Berbasis Multietnik. Yogyakarta: CV Budi Utama, 2015.

Mardapi, Djemari. pengukuran, penilaian, dan evaluasi pendidikan. Yogyakarta: Nuha Medik, 2012

Muhaimin. Pengembangan Kurikulum Pendidikan Agama Islam di Sekolah. Jakarta: Rajawali Pers, 2014.

Mulyasa, E. Standar Kompetensi dan Sertifikasi Guru. Bandung: Remaja Rosdakarya, 2011.

Mulyasa, E. Guru dalam Implementasi Kurikulum 2013. Bandung: Remaja Rosdakarya, 2014.

Mulyasa, E. Pengembangan dan Implementasi Kurikulum 2013. Bandung: Remaja Rosdakarya Offset, 2013.

Nur Kholis, Moch. wawancara, Gresik, 19 November 2019.

Ramayulis, H. Ilmu Pendidikan Islam. Jakarta : Kalam Mulia, 2002

Sofyan, Ahmad. wawancara, Gresik, 19 November 2019.

Sugiono. Metode Penelitian Kuantitatif, Kualitatif, dan R\&D. Bandung. Alfabeta, t.t.

Sulistya Ningrum, Elwien dan Ahmad Yusuf Sobri. "Implementasi Kurikulum 2013 di sekolah dasar", Jurnal Manajemen Pendidikan, No. 5, Vol. 24, Maret, 2015.

Undang-undang Republik Indonesia No.14 tahun 2005, tentang Guru dan Dosen. Bandung: Citra Umbara, 2006.

Uzer Usman, Moh. Menjadi Guru Profesional. Bandung: Remaja Rosdakarya, 2005. 